\title{
PEMANFAATAN CANGKANG KERANG DARAH (ANADARA GRANOSA) DAN ZEOLIT SEBAGAI MEDIA FILTER KERAMIK UNTUK PENGOLAHAN AIR GAMBUT
}

Muchlis $^{1)}$ Kiki Prio Utomo ${ }^{1)}$ Ulli Kadaria ${ }^{1)}$

1) Program Studi Teknik Lingkungan Jurusan Teknik Sipil Fakultas Teknik Universitas Tanjungpura, Pontianak Email : muchlis.vatriadi@gmail.com

\begin{abstract}
ABSTRAK
Kalimantan Barat sebagian besar memiliki lahan gambut yaitu sekitar 1,7 juta hektar. Masyarakat yang tidak mendapatkan akses air bersih menggunakan air sumur sebagai air baku untuk minum. Air gambut secara umum tidak memenuhi persyaratan kualitas air minum berdasakan PERMENKES No.492 Tahun 2010 karena memiliki ciri-ciri intensitas warna yang tinggi, $\mathrm{pH}$ asam, kandungan zat organik tinggi, dan kandungan logam besi yang tinggi. Penelitian ini bertujuan untuk mengetahui kinerja filter keramik dengan campuran media filter cangkang kerang darah (Anadara Granosa) dan zeolit untuk pengolahan air gambut. Filter keramik dibuat dari campuran zeolit dan cangkang kerang darah (Anadara Granosa) dengan perekat Polivinil Alkohol (PVA) yang disintering dengan suhu $250^{\circ} \mathrm{C}$ selama 2 jam. Variasi komposisi bahan cangkang kerang darah dan zeolit yang dibuat adalah 25\%:75\%, 50\%:50\% dan 75\%:25\% dengan perekat PVA masing-masing sebanyak 1 gram. Penelitian dilakukan dengan melewatkan air gambut pada filter keramik, kemudian dilakukan karakterisasi fisik filter keramik serta uji laboratorium sebelum dan setelah pengolahan. Hasil penelitian menunjukkan filter keramik dengan campuran cangkang kerang darah dan zeolit untuk masing-masing komposisi 25\%:75\% (F1), 50\%:50\% (F2) dan 75\%:25\% (F3) yaitu memiliki densitas sebesar 1,53 $\mathrm{gr} / \mathrm{cm}^{3}, 1,56 \mathrm{gr} / \mathrm{cm}^{3}$ dan $1,58 \mathrm{gr} / \mathrm{cm}^{3}$, porositas sebesar $49,61 \%, 55,12 \%$ dan $60,63 \%$, dan fluks sebesar $7,4 \mathrm{~L} / \mathrm{m}^{2}$.jam, 5,9 L/m².jam, dan 2,8 L/m².jam. Filter keramik dengan perbandingan $75 \%: 25 \%$ (F3) efektif meningkatkan $\mathrm{pH}$ air gambut dari 4,4 menjadi 6,5 dengan efektivitas sebesar $52,27 \%$ dan menurunkan parameter besi dari $0,577 \mathrm{mg} / \mathrm{L}$ menjadi $0,487 \mathrm{mg} / \mathrm{L}$ dengan efektifitas sebesar $15,6 \%$, sedangkan filter keramik dengan perbandingan $25 \%: 75 \%$ (F1) dapat menurunkan zat organik dari $334,9 \mathrm{mg} / \mathrm{L}$ menjadi $322,3 \mathrm{mg} / \mathrm{L}$ dengan efektifitas sebesar $3,76 \%$.
\end{abstract}

Kata Kunci : air gambut, filter keramik, kerang darah

\begin{abstract}
West Kalimantan has mostly peat which is about 1.7 million hectares. People who are not getting access to clean water using a water well as raw water for drinking. Water peat is generally not good based on the requirements of the drinking water quality PERMENKES No. 492 in 2010 because it has the characteristics of high color intensity, acid $\mathrm{pH}$, organic matter content is high, and a high content of iron metal. This research aims to know the performance of ceramic filter material with a mixture of shells of blood clams (Anadara Granosa) and zeolite for peat water treatment. Ceramic filter made from a mixture of shells (Anadara Granosa) and zeolite with adhesive Polyvinyl alcohol (PVA) and burned with a temperature of $2500 \mathrm{C}$ for 2 hours. Variations in the composition of the material shells of blood clams and zeolite made of 25\%:75\%(F1), 50\%:50\%(F2) and 75\%:25\%(F3) with PVA adhesive to each of as many as 1 gram. Research done by passing peat water on ceramic filter, and then do the physical characterization of ceramic filters and laboratory test before and after processing. The results showed a ceramic filter with a mixture of zeolite and shells for each composition: $25 \%, 75 \%(F 1), 50 \%: 50 \%(F 2)$ and $75 \%: 25 \%(F 3)$ is the density $1,53 \mathrm{gr} / \mathrm{cm} 3,1,56 \mathrm{gr} / \mathrm{cm} 3$ and $1,58 \mathrm{gr} / \mathrm{cm} 3$, porosity $49,6 \%, 55,1 \%$ and $60,6 \%$, and the flux $7.4 \mathrm{~L} / \mathrm{m} 2 . h, 5,9 \mathrm{~L} / \mathrm{m} 2 . h$ and 2,8 L/m2.h. Ceramic filter by comparison $75 \%: 25 \%$ (F3) effective improve the $\mathrm{pH}$ of water peat from 4.4 be 6.5 with effectivity $52,27 \%$ and reduced iron parameter of $0,577 \mathrm{mg} / \mathrm{L}$ be $0,487 \mathrm{mg} / \mathrm{L}$ with effectivity $15.6 \%$, while in comparison with ceramic filters $25 \%: 75 \%(F 1)$ can reduce the content of organic matter from $334,9 \mathrm{mg} / \mathrm{L}$ be $322,3 \mathrm{mg} / \mathrm{L}$ with effectivity 3,76\%.
\end{abstract}

Keywords: blood clams, ceramic filters, peat 


\section{PENDAHULUAN}

Di Kalimantan Barat yang sebagian besar memiliki lahan gambut yaitu sekitar 1,7 juta hektar, masyarakat yang tidak mendapatkan akses air bersih menggunakan air sumur sebagai air baku untuk minum. Air gambut secara umum tidak memenuhi persyaratan kualitas air minum, berdasarkan Data Dinas Kesehatan Provinsi Kalimantan Barat tahun 2008, kualitas air gambut di Kalimantan Barat memiliki ciri-ciri kekeruhan yang rendah, berwarna coklat tua dan kehitaman (124 - 850 unit Pt-Co), kadar organik tinggi ( $138-1560 \mathrm{mg} / \mathrm{L} \mathrm{KMnO4)}$ dan bersifat asam ( $\mathrm{pH} \mathrm{3,7} \mathrm{-} \mathrm{5,3),} \mathrm{sedangkan}$ berdasarkan baku mutu air minum menurut PERMENKES No. 492/MENKES/PER/IV/2010, kadar pH normal yang diperbolehkan untuk air minum berkisar antara 6,8-8,5, zat organik sebesar $10 \mathrm{mg} / \mathrm{L}$ dan warna adalah $15 \mathrm{Pt}$-Co. Oleh karena itu apabila air gambut digunakan sebagai air minum maka harus melalui pengolahan terlebih dahulu.

Keramik berpori adalah keramik yang mempunyai rongga-rongga kecil yang menyebabkan fluida (porinya $30-70 \%$ ) dapat masuk ke dalam dan dapat berfungsi sebagai filter sehingga lebih dikenal sebagai filter keramik berpori. Salah satu media filter yang dapat dijadikan filter keramik adalah cangkang kerang. Hasil penelitian Hanafi (2015), menunjukkan bahwa jenis cangkang kerang darah dapat meningkatkan kadar pH dari 4,47 menjadi 7,21-7,90 dan menurunkan warna air gambut sebesar 52,55\% dengan metode filtrasi. Kandungan kapur yang tinggi pada cangkang kerang darah dapat menjadi pengikat (binder) dalam pembuatan filter keramik yang dikombinasikan dengan media filter zeolit sebagai pembentuk pori. Berdasarkan penelitian Akbar (2010), penggunaan zeolit sebagai filter keramik dengan komposisi $75 \%$ ( $25 \%$ bahan pengikat) dapat memisahkan 99,2 \% ion Fe dan mampu menjernihkan kekeruhan air. Sedangkan berdasarkan penelitian Sandra (2014), campuran zeolit 75\% dan 25\% bahan adiktif dapat menurunkan kadar Fe dari 3,8 ppm-0,28 ppm, untuk mengetahui pengaruh cangkang kerang darah dan zeolit dalam pengolahan air gambut, maka dilakukan penelitian pengolahan air gambut menggunakan cangkang kerang darah dan zeolit sebagai media filter untuk menentukan campuran efektif dalam pengolahan air gambut menjadi air minum

\section{METODOLOGI PENELITIAN}

\section{a. Lokasi sampel}

Air baku yang diolah menjadi air bersih adalah air permukaan yang berasal dari sumur dangkal yang terdapat di Jl. Sungai Raya Dalam, Komplek Srikandi.

\section{b. Alat dan bahan}

Adapun peralatan yang digunakan dalam penelitian ini adalah tabung $(\mathrm{d}=4,5 \mathrm{~cm}$, $\mathrm{t}=20 \mathrm{~cm})$, modul filter $(\mathrm{d}=2,15 \mathrm{~cm}, \mathrm{t}=0,5 \mathrm{~cm})$, gelas ukur $500 \mathrm{ml}$, botol sampling 1 liter, saringan partikel (sieve) no.45 dan 80, statif, furnace, oven listrik, neraca digital, mortar batu dan kain halus, sedangkan bahan yang digunakan adalah sampel air gambut 6 liter, aquades, Polivinil alkohol (PVA) 300 gram, cangkang kerang darah (Anadara Granosa) 60 gram dan zeolit 60 gram.

\section{c. Metode Penelitian}

- Tahap Preparasi Media Filter

Cangkang kerang dan zeolit dicuci hingga bersih untuk mnghilangkan kotoran dan lumut yang menempel. Cangkang kerang yang sudah bersih dipanaskan 
menggunakan oven pada suhu $\pm 105^{\circ} \mathrm{C}$ hingga kering dan beratnya konstan. Cangkang kerang yang sudah bersih dihaluskan menggunakan mortar batu yang dilapisi kain halus hingga berbentuk butiran halus. Tahap selanjutnya dilakukan pengayakan menggunakan dua pengayak (test-siever) yang disusun besar-kecil yaitu no.45 $(355 \mu \mathrm{m})$ dan no.80 (180 $\mu \mathrm{m})$. Serbuk cangkang kerang yang akan digunakan adalah partikel yang lolos saringan 355 um dan tertahan pada saringan $180 \mu \mathrm{m}$.

\section{- Tahap Pembuatan Filter Keramik}

Filter keramik dibuat dari campuran zeolit dan cangkang kerang darah sebanyak 11 gram. Zeolit dan cangkang kerang darah ditimbang menggunakan neraca digital dengan perbandingan 75\%:25\% (F1), 50\%:50\% (F2), dan 25\%:75\% (F3). Setelah itu dimasukkan kedalam wadah yang dilapisi plastik dan dihomogenkan. Secara perlahan ditambahkan perekat PVA masing-masing 1 gram dan akuades hingga berbentuk pasta. Tahap selanjutnya dilakukan pencetakan filter keramik dengan menuangkan pasta (campuran zeolit dan cangkang kerang) ke dalam modul/cetakan dengan diameter 4,3 $\mathrm{cm}$ dan tinggi cetakan $0,5 \mathrm{~cm}$. Setelah itu pindahkan ke dalam oven pada temperatur $\pm 29^{\circ} \mathrm{C}$ (dalam keadaan off) selama $3 \times 24$ jam. Filter keramik yang telah mengeras kemudian dikeluarkan dari cetakannya, selanjutnya dilakukan sintering pada suhu $250^{\circ} \mathrm{C}$ selama 2 jam.

\section{d. Rangkaian Alat Uji}

Alat uji dibuat menggunakan penyangga statif yang digunakan sebagai dudukan untuk tabung filter. Air hasil pengolahan akan ditampung menggunakan gelas ukur yang terdapat pada bagian outlet filter.

Gambar 1. Rangkaian alat dan modul filter

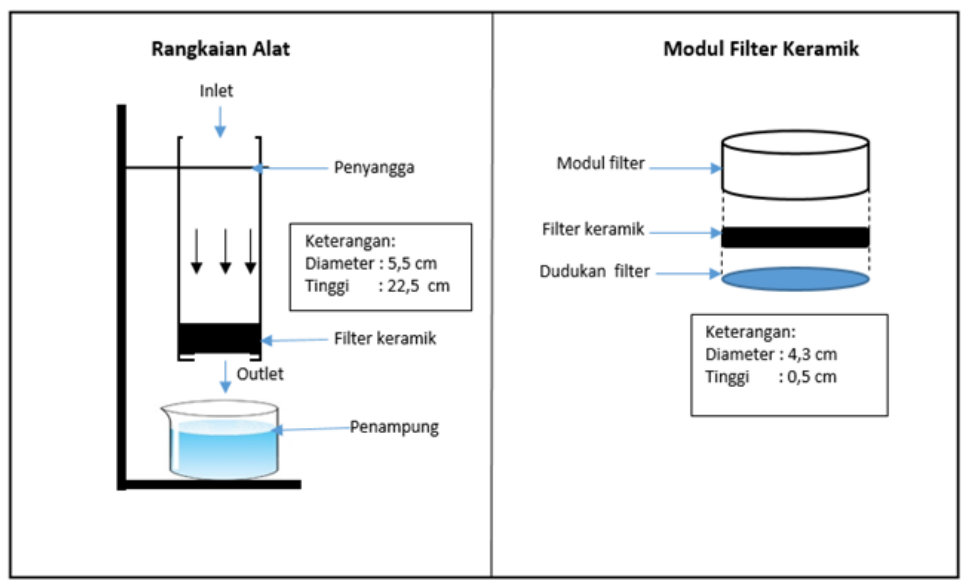

\section{e. Analisis Data}

\section{Densitas}

Densitas merupakan pengukuran massa setiap satuan volume benda. Semakin tinggi densitas (massa jenis) suatu benda, maka seakin besar pula massa setiap volumenya. Menghitung besarnya densitas digunakan persamaan matematis berikut (Irawati, 2016):

$$
\rho=\frac{M}{V}
$$


Keterangan:

$$
\begin{array}{ll}
\rho & =\text { Densitas }\left(\mathrm{gr} / \mathrm{cm}^{3}\right) \\
\mathrm{M} & =\text { Massa kering }(\mathrm{gr}) \\
\mathrm{V} & =\text { Volume }\left(\mathrm{cm}^{3}\right)
\end{array}
$$

\section{Porositas}

Porositas adalah ukuran dari proporsi total yang ditempati oleh pori-pori, dan biasanya dinyatakan sebagai persentase dari volume sampel Secara matematis dapat dirumuskan sebagai berikut (Lawrence H Van Vlack, 1989 dalam Irawati, 2016 ):

$$
\text { Porositas }=\frac{(\mathrm{mb}-\mathrm{mk}) / \text { pair }}{\mathrm{Vt}} \times 100 \%
$$

Keterangan:

$\mathrm{mb}=$ Massa basah (gr)

$\mathrm{mk} \quad=$ Massa kering (gr)

$\mathrm{Vt} \quad=$ Volume total $\left(\mathrm{cm}^{3}\right)$

pair $\quad=1000 \mathrm{~kg} / \mathrm{m}^{3}=1 \mathrm{gr} / \mathrm{cm}^{3}$

\section{Fluks}

Laju aliran atau fluks adalah ukuran kecepatan suatu spesi melewati membran persatuan luas dan waktu dengan gradien tekanan sebagai gaya pendorong. Besar fluks filter keramik dapat ditentukan dengan persamaan matematis berikut (Richardson et al, 2002):

$$
J v=\frac{V}{A x t}
$$

Keterangan:

$\mathrm{Jv} \quad=$ Fluks $\left(\mathrm{L} / \mathrm{m}^{2} . \mathrm{jam}\right)$

$\mathrm{V} \quad=$ Volume permeat $(\mathrm{L})$

A $\quad=$ Luas permukaan $\left(\mathrm{m}^{2}\right)$

$\mathrm{t} \quad=$ Waktu (jam)

\section{Efektivitas}

$$
\text { Efektivitas }=\frac{\mathrm{a}-\mathrm{b}}{a} \times 100 \%
$$

Keterangan:

$\mathrm{a}=$ Konsentrasi sebelum pengolahan

$\mathrm{b}=$ Konsentrasi setelah pengolahan

\section{HASIL DAN PEMBAHASAN}

\section{a. Hasil Analisis Kualitas Air Baku}

Air baku yang diolah menjadi air bersih adalah air permukaan yang berasal dari sumur dangkal yang terdapat di Jl. Sungai Raya Dalam, Komplek Srikandi. Air baku dilakukan uji laboratorium sebagai data awal penelitian. Adapun hasil uji kualitas air baku dapat dilihat pada Tabel 1. 
Tabel 1. Hasil uji kualitas air gambut

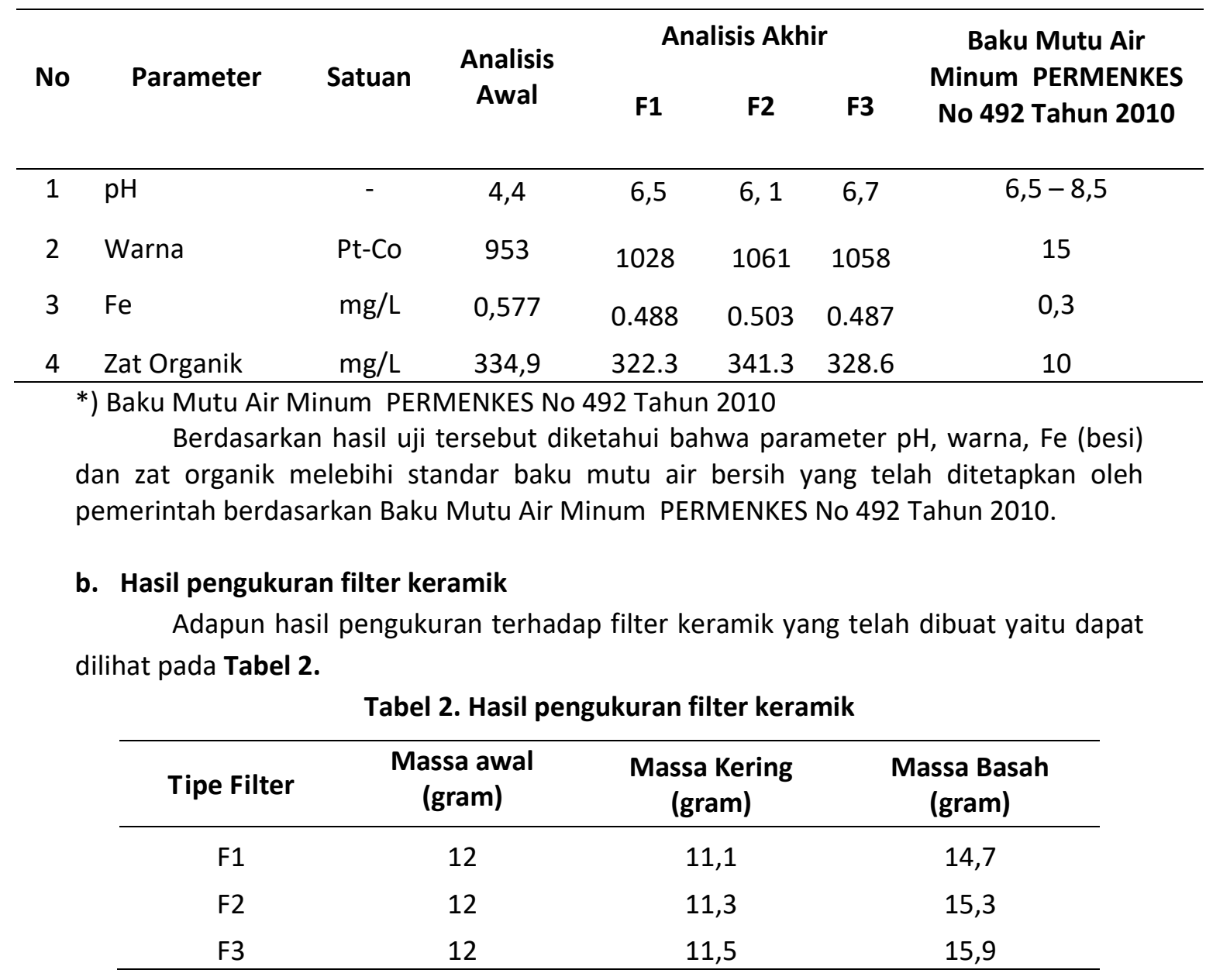

Data hasil pengukuran massa kering dan massa basah filter keramik digunakan untuk mendapatkan nilai densitas dan porositas menggunakan persamaan (1) dan (2).

\section{c. Karakteristik Filter Keramik}

Adapun karakteristik filter keramik dari campuran zeolit dan cangkang kerang darah yaitu dapat dilihat pada Tabel 3.

Tabel 3. Karakteristik filter keramik

\begin{tabular}{cccc}
\hline Tipe Filter & Densitas (gr/cm $\left.{ }^{3}\right)$ & Porositas (\%) & Fluks (L/m $\mathbf{~}^{\mathbf{. j a m})}$ \\
\hline F1 & 1,53 & 49,6 & 7,4 \\
F2 & 1,56 & 55,1 & 5,9 \\
F3 & 1,58 & 60,6 & 2,8 \\
\hline
\end{tabular}

Hasil pengukuran menunjukkan densitas terbesar dicapai pada perbandingan komposisi zeolit terhadap cangkang kerang darah 75\% : 25\% (Tipe filter F3) yaitu sebesar $1,58 \mathrm{gr} / \mathrm{cm}^{3}$. Perbandingan 50\% : 50\% (Tipe filter F2) memiliki densitas sebesar 1,56 $\mathrm{gr} / \mathrm{cm}^{3}$, sedangkan pada perbandingan $25 \%: 75 \%$ (Tipe filter $\mathrm{F} 1$ ) yaitu sebesar 1,53 $\mathrm{gr} / \mathrm{cm}^{3}$. Hal ini menunjukkan bahwa semakin banyak bahan aditif zeolit terhadap bahan 
pengikatnya (cangkang kerang darah) maka semakin rendah densitas yang dihasilkan, sebaliknya semakin sedikit bahan aditif maka densitas yang dihasilkan akan semakin besar. Semakin tinggi densitas filter maka akan menyebabkan semakin tinggi kerapatannya, kerapatan yang tinggi akan menghasilkan rongga antar partikel yang lebih kecil, sebaliknya kerapatan yang rendah akan menghasilkan pori yang besar sehingga kemampuan daya serap filter terhadap air semakin besar (Sebayang, 2009)

Hasil pengukuran porositas menunjukkan nilai porositas tertinggi terdapat pada perbandingan komposisi cangkang kerang darah dan zeolit 75\%:25\% (Tipe filter F3) yaitu sebesar $60,63 \%$. Pada perbandingan $50 \%$ : 50\% (Tipe filter F2) didapatkan nilai porositas sebesar $55,12 \%$. Sedangkan nilai porositas terendah terdapat pada filter dengan perbandingan 25\% : 75\% (Tipe filter F1) yaitu sebesar 49,61\%. Densitas dan porositas berhubungan satu sama lain, yaitu semakin besar densitas suatu benda akan memiliki rongga (pori) yang lebih kecil sehingga porositas yang dihasilkan akan semakin besar.

Hasil pengukuran fluks menunjukkan nilai fluks tertinggi terdapat pada perbandingan 25\% : 75\% (Tipe filter F1) dengan nilai fluks 7,40 L/m².jam, perbandingan 50\% : 50\% (Tipe filter F2) menghasilkan nilai fluks sebesar 5,92 L/m².jam, sedangkan nilai fluks pada perbandingan $75 \%: 25 \%$ (Tipe filter F3) yaitu sebesar $2,82 \mathrm{~L} / \mathrm{m}^{2}$.jam. Hal ini menunjukkan bahwa semakin banyak komposisi bahan aditif zeolit terhadap bahan pengikatnya (cangkang kerang darah) maka semakin besar nilai fluks yang dihasilkan, sebaliknya semakin kecil komposisi bahan aditif maka semakin rendah nilai fluks yang dihasilkan.

\section{d. Pengaruh Perbandingan Media Filter Terhadap Kualitas Air Gambut}

1. $\mathrm{pH}$

Hasil pengukuran parameter $\mathrm{pH}$ untuk masing-masing perbandingan komposisi filter keramik yaitu dapat dilihat pada Gambar 5.

Pengaruh komposisi cangkang kerang darah dan zeolit terhadap derajat keasaman $(\mathrm{pH})$

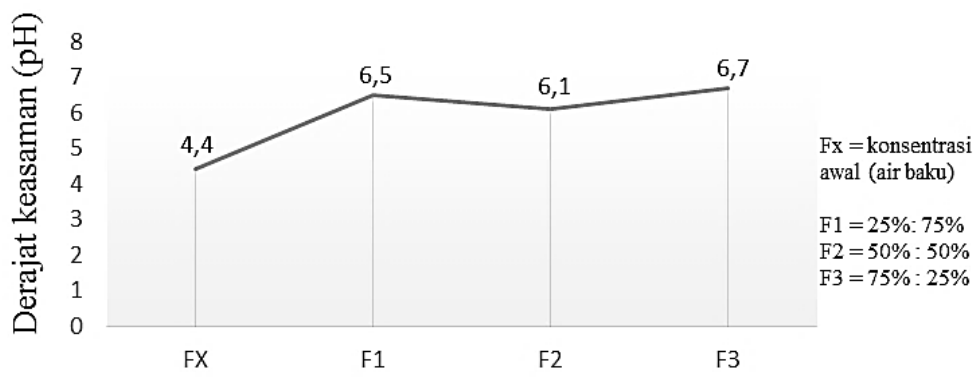

Tipe Filter

Gambar 5. Pengaruh perbandingan komposisi zeolit dan cangkang kerang darah terhadap parameter $\mathrm{pH}$

Peningkatan nilai $\mathrm{pH}$ paling maksimum pada perbandingan komposisi cangkang kerang darah dan zeolit sebesar 75\%:25\% (Tipe Filter 3) dimana $\mathrm{pH}$ awal 4,4 naik menjadi 6,7. Hal ini dikarenakan tipe filter $\mathrm{F} 3$ memiliki kandungan $\mathrm{CaCO}_{3}$ paling banyak dibandingkan tipe filter lainnya dengan komposisi cangkang kerang darah $75 \%$. Penggunaan cangkang kerang darah ${ }^{+}$menurut Hanafi (2015) cangkang kerang darah yang mengandung $\mathrm{CaCO} 3$ dapat meningkatkan $\mathrm{pH}$ air gambut dari 4,47 menjadi netral yaitu 
7,21 - 8,09. Cangkang kerang yang digunakan sebagai media filter sebagian besar mengandung 98,7\% $\mathrm{CaCO}_{3}$ (kalsium karbonat) (Awang-Hazmi et al, 2007), yang jika $\mathrm{CaCO}_{3}$ dilarutkan dalam air akan melepaskan ion $\mathrm{OH}-$, sehingga jumlah $\mathrm{OH}$ - dalam air akan semakin banyak. Pada perbandingan komposisi cangkang kerang darah terhadap zeolit 25\%: 75\% (Tipe Filter 1) terjadi kenaikan nilai $\mathrm{pH}$ dari 4,4 menjadi 6.5, sedangkan peningkatan nilai $\mathrm{pH}$ pada perbandingan 50\%:50\% (Tipe Filter 2) lebih rendah, yaitu sebesar 6,1. Hal ini dapat diakibatkan oleh besarnya konsentrasi $\mathrm{H}^{+}$dibandingkan $\mathrm{OH}^{-}$ dalam air yang menyebabkan $\mathrm{pH}$ lebih rendah. Konsentrasi $\mathrm{H}^{+}$didalam air gambut berasal dari proses pembentukan $\mathrm{CO}_{2}$. Karbondioksida $\left(\mathrm{CO}_{2}\right)$ dalam air seringkali terdapat sebagai $\mathrm{H}_{2} \mathrm{CO}_{3}$, sehingga ketika pembentukan $\mathrm{CO}_{2}$ maka $\mathrm{H}_{2} \mathrm{CO}_{3}$ akan melepaskan $\mathrm{H}^{+}$.

Cangkang kerang darah yang mengandung $\mathrm{CaCO}_{3}$ yang bersifat basa dapat meningkatkan $\mathrm{pH}$ air gambut yang bersifat asam Adapun reaksi yang terjadi jika $\mathrm{CaCO}_{3}$ dilarutkan dalam air akan menyebabkan $\mathrm{CaCO}_{3}$ terurai yaitu:

$\mathrm{CaCO}_{3}(\mathrm{~s}) \longrightarrow \mathrm{Ca}^{2+}(\mathrm{aq})+\mathrm{CO}_{3}^{2-}(\mathrm{aq})$ (Novita, 2008)

$\mathrm{CO}_{3}{ }^{2-}$ di dalam air akan mengalami reaksi hidrolisis:

$$
\mathrm{CO}_{3}{ }^{2-}(\mathrm{aq})+2 \mathrm{H}_{2} \mathrm{O}(\mathrm{I}) \longrightarrow \mathrm{H}_{2} \mathrm{CO}_{3}(\mathrm{aq})+2 \mathrm{OH}^{-}(\mathrm{aq})
$$

Sedangkan $\mathrm{H}_{2} \mathrm{CO}_{3}$ akan langsung terurai menjadi $\mathrm{H}_{2} \mathrm{O}$ dan $\mathrm{CO}_{2}$ berdasarkan reaksi:

$$
\mathrm{H}_{2} \mathrm{CO}_{3}(\mathrm{aq}) \longrightarrow \mathrm{H}_{2} \mathrm{O}(\mathrm{I})+\mathrm{CO}_{2} \text { (g) (Prodjosantoso, 2011) }
$$

Sehingga ketika $\mathrm{CaCO}_{3}$ (kalsium karbonat) direaksikan dengan $\mathrm{H}_{2} \mathrm{O}$ (air) maka reaksinya adalah sebagai berikut:

$$
\mathrm{CaCO}_{3}(\mathrm{~s})+\mathrm{H}_{2} \mathrm{O}(\mathrm{I}) \longrightarrow \mathrm{Ca}(\mathrm{OH})_{2}(\mathrm{aq})+\mathrm{CO}_{2}(\mathrm{~g}) \text { (Mariyono, 2011) }
$$

\section{Warna}

Hasil pengukuran parameter warna untuk masing-masing perbandingan komposisi filter keramik yaitu dapat dilihat pada Gambar 6 .

Pengaruh komposisi cangkang kerang darah dan zeolit terhadap warna

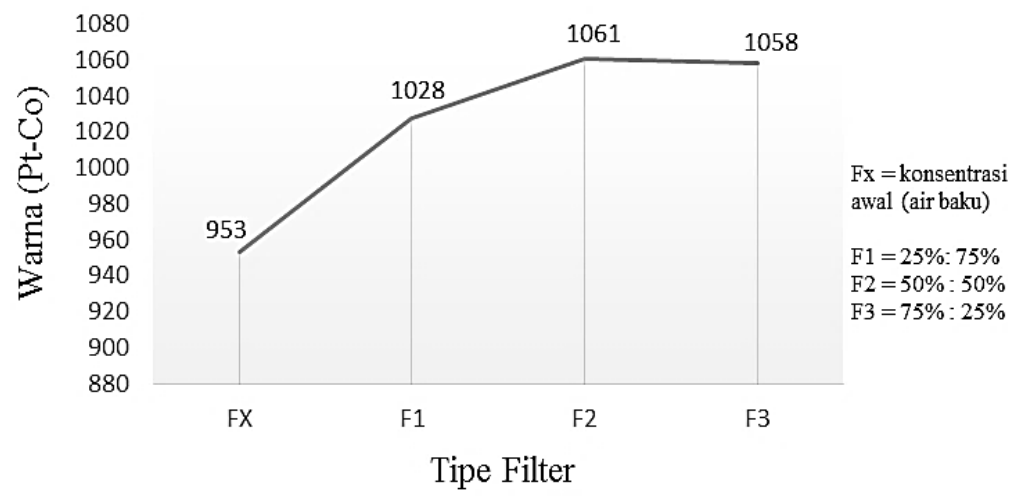

Gambar 6. Pengaruh perbandingan komposisi zeolit dan cangkang kerang darah terhadap parameter warna

Pengolahan air gambut menggunakan filter keramik dengan campuran cangkang kerang darah dan zeolit untuk parameter warna medapatkan nilai efektifitas negatif, yaitu hasil pengolahan mengalami kenaikan. Sulitnya penyisihan warna pada air gambut dapat diakibatkan warna sejati air gambut yang tinggi akibat adanya besi terlarut dan zat 
organik dalam air. Terdapatnya zat organik, khususnya dalam bentuk humat dan humin menyebabkan warna air menadi tinggi dan sulit dihilangkan karena penyaringan atau filtrasi hanya dapat menurunkan warna tampak yang diakibatkan adanya zat tersuspensi dalam air.

Terdapat penambahan warna pada air gambut setelah mengalami pengolahan yaitu dari 953 Pt-Co menjadi 1028 Pt-Co untuk tipe filter F1, 1061 Pt-Co untuk tipe filter F2 dan 1058 untuk tipe filter F3. Hal ini dapat diakibatkan meningkatnya zat tersuspensi pada air hasil olahan yang disebabkan oleh kontribusi cangkang kerang darah dan zeolit yang terlarut karena dalam pembuatan filter keramik ini cangkang kerang darah dan zeolit ini dihaluskan atau berukuran sangat kecil. Hal ini juga terjadi pada penelitian sebelumnya yang menggunakan cangkang kerang darah sebagai media filter yaitu Hanafi (2015) dan Fajarwati (2014) dimana terjadi penambahan warna pada air hasil pengolahan menjadi lebih pekat dan keruh. Penambahan warna yang berasal dari cangkang kerang darah merupakan reaksi antara kalsium karbonat $\left(\mathrm{CaCO}_{3}\right)$ dan air gambut $\left(\mathrm{H}_{2} \mathrm{O}\right)$ yang menghasilkan kalsium hidroksida $\left(\mathrm{Ca}(\mathrm{OH})_{2}\right)$ atau umumnya disebut sebagai air kapur. Kalsium hidroksida atau yang disebut sebagai air kapur dapat dengan mudah larut dalam air yang memiliki sifat asam (Mariyono, 2011).

\section{Besi}

Hasil pengukuran parameter Fe (besi) untuk masing-masing perbandingan komposisi filter keramik yaitu dapat dilihat pada Gambar 7

Pengaruh komposisi cangkang kerang darah dan zeolit terhadap besi

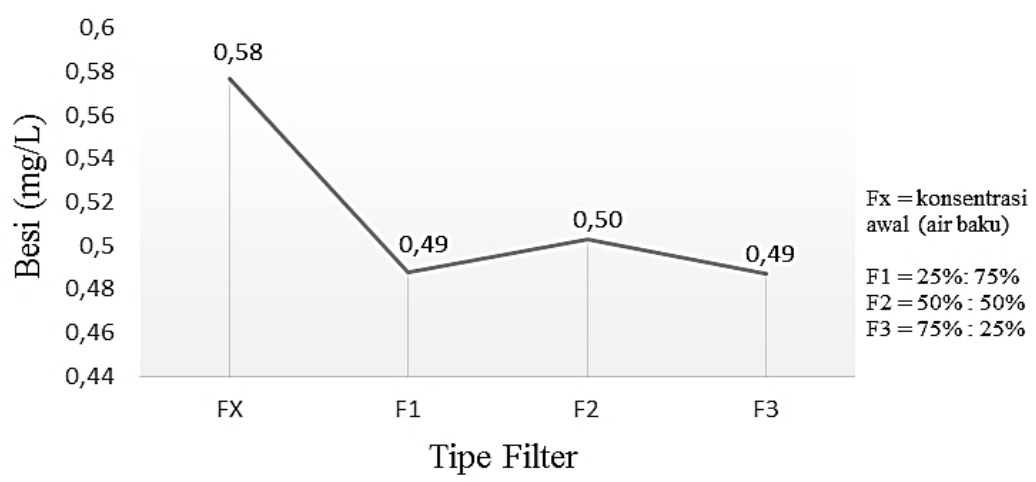

Gambar 7. Pengaruh perbandingan komposisi zeolit dan cangkang kerang darah terhadap parameter besi

Penurunan parameter besi untuk masing-masing tipe filter tidak terlalu signifikan. Penurunan besi paling tinggi pada pengolahan menggunakan filter keramik dengan perbandingan komposisi cangkang kerang darah dan zeolit 25\% : 75\% (Tipe Filter F1) dan $75 \%: 25 \%$ (Tipe Filter F3) yaitu dari konsentrasi 0,58 menjadi 0,49 dengan efektifitas sebesar $15,6 \%$, sedangkan pada perbandingan komposisi cangkang kerang darah dan zeolit 50\%: 50\% (Tipe Filter F2) tidak terlalu signifikan dan terlalu jauh dari tipe filter F2 dan F3 yaitu dari 0,58 menjadi 0,50 dengan efektifitas sebesar $12,82 \%$. Hal ini dikarenakan hal ini dikarenakan pada $\mathrm{pH}$ asam yaitu $\mathrm{pH} 4,4$ besi terlarut dalam air sebagai $\mathrm{Fe} 2+$ sedangkan pada $\mathrm{pH}$ 6-8 besi terdapat dalam bentuk $\mathrm{Fe}^{3+}$ yang sulit larut dalam air sehingga dapat lebih mudah dipisahkan dengan air pada proses filtrasi. Proses penyisihan besi yang teradi pada pengolahan menggunakan filter keramik ini merupakan 
proses adsorbsi fisik, karena perbedaan komposisi cangkang kerang darah dan zeolit tidak menunjukkan perbedaan hasil yang signifikan. Menurut Mu'izah (2010), umumnya adsorbsi ion logam dari larutan ke permukaan adsorben merupakan adsorbsi fisik dimana gaya yang bekerja antar logam berat dari permukaan adsorben adalah gaya Van der Walls dimana tidak teradi reaksi secara kimia atau pengikatan secara ionik logam dengan adsorben.

\section{Zat Organik}

Hasil pengukuran parameter zat organik untuk masing-masing perbandingan komposisi filter keramik yaitu dapat dilihat pada Gambar 8.

Pengaruh komposisi cangkang kerang darah dan zeolit terhadap zat organik

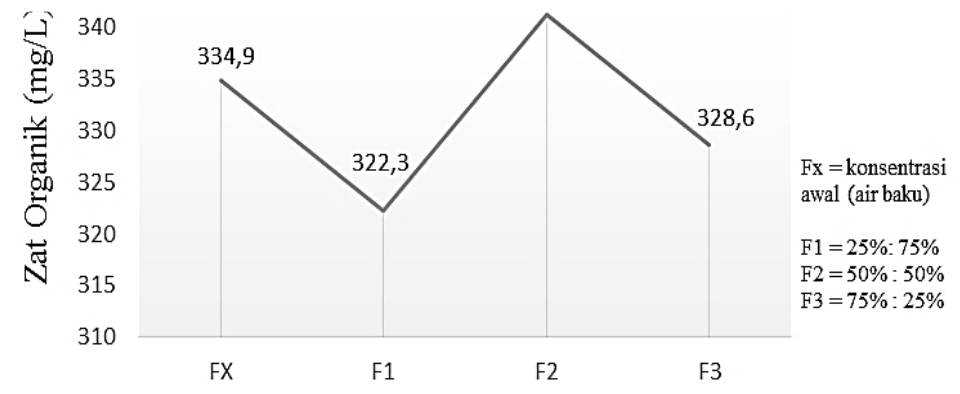

Tipe Filter

Gambar 8. Pengaruh perbandingan komposisi zeolit dan cangkang kerang darah terhadap parameter zat organik

Penurunan zat organik pada pengolahan menggunakan filter keramik tidak terlalu signifikan yaitu penurunan tertinggi pada perbandingan komposisi cangkang kerang darah dan zeolit 25\%: $75 \%$ (Tipe Filter F1) yaitu dari 334,9 mg/L menjadi 322,3 $\mathrm{mg} / \mathrm{L}$ dengan efektifitas sebesar 3,76\% . Hal ini dikarenakan pada tipe filter F1 memiliki komposisi atau kandungan zeolit yang paling banyak yaitu $75 \%$. Penurunan zat organik ini disebabkan adanya proses adsorbsi oleh media filter zeolit. Pada pengolahan menggunakan filter keramik dengan campuran cangkang kerang darah dan zeolit $75 \%$ : 25\% (Tipe Filter F3), kandungan zat organik pada air gambut mengalami penurunan dari $334,9 \mathrm{mg} / \mathrm{L}$ menjadi $328,6 \mathrm{mg} / \mathrm{L}$ dengan efektifitas sebesar $1,88 \%$.

Pada pengolahan menggunakan filter keramik dengan campuran cangkang kerang darah dan zeolit 50\% : 50\% (Tipe Filter F2) mengalami kenaikan zat organik yaitu dari $334,9 \mathrm{mg} / \mathrm{L}$ menjadi $341,3 \mathrm{mg} / \mathrm{L}$ atau terjadi kenaikan sebesar 1,91 \%. Terjadinya kenaikan kandungan organik pada hasil pengolahan ini dapat disebabkan oleh adanya kotoran yang tidak tersaring pada proses filtrasi dan tersuspensi di dalam air sehingga mengalami penguraian di dalam botol penyimpanan sementara sebelum dilakukan pengujian laboratorium. Terdapatnya kotoran dalam air akan menyebabkan peningkatan zat organik karena umumnya kotoran yang terdapat dalam air gambut berupa bagian dari tanaman yang terdekomposisi yang merupakan zat organik. 


\section{KESIMPULAN}

Berdasarkan hasil penelitian pemanfaatan cangkang kerang darah (Anadara Granosa) dan zeolit sebagai media filter keramik untuk pengolahan air gambut dapat disimpulkan bahwa:

1. Filter keramik dari campuran bahan cangkang kerang darah dan zeolit memiliki densitas sebesar $1,53 \mathrm{gr} / \mathrm{cm} 3(\mathrm{~F} 1), 1,56 \mathrm{gr} / \mathrm{cm} 3(\mathrm{~F} 2)$ dan $1,58 \mathrm{gr} / \mathrm{cm} 3$ (F3), porositas sebesar $49,61 \%(F 1), 55,12 \%(F 2)$ dan $60,63 \%(F 3)$, dan fluks sebesar 7,4 $\mathrm{L} / \mathrm{m} 2$.jam(F1), 5,9 L/m2.jam(F2), dan 2,8 L/m2.jam(F3).

2. Filter keramik dengan perbandingan cangkang kerang darah dan zeolit $75 \%: 25 \%$ (Tipe filter F3) efektif menaikkan $\mathrm{pH}$ dari 4,4 menjadi 6,7 dan menurunkan logam besi sebesar $15,6 \%$ sedangkan filter keramik dengan perbandingan cangkang kerang darah dan zeolit 25\%:75\% (Tipe filter F1) dapat menurunkan zat organik sebesar 3,8\%.

3. Kualitas air gambut untuk parameter besi, warna dan zat organik setelah dilakukan pengolahan menggunakan filter keramik belum memenuhi baku mutu air minum berdasarkan PERMENKES No.492 Tahun 2010.

\section{UCAPAN TERIMA KASIH}

Saya mengucapkan terima kasih yang sebesar-besarnya kepada Bapak Kiki Prio Utomo ST. M.Sc dan Ibu Ulli Kadaria ST.MT selaku dosen pembimbing, RAMP-IPB selaku mentoring ide dan inovasi, Laboratorium Teknik Lingkungan dan Laboratorium Fisika MIPA UNTAN yang telah berperan dalam penelitian ini. Harapan saya penelitian ini dapat bermanfaat bagi semua dan dapat dipergunakan sebagaimana mestinya.

\section{DAFTAR PUSTAKA}

Akbar, M.Ali. 2010. Pembuatan Membran Mikrofilter Zeolit Alam dengan Penambahan Semen Putih Portland. UIN Syarif Hidayatullah: Jakarta

Hanafi, 2015. Optimasi Filter Cangkang Kerang Darah (Anadara Granosa) untuk Meningkatkan Kualitas Air Gambut (Skripsi). Universitas Tanjungpura: Pontianak

Irawati, Ade. 2016. Kinerja Statis Campuran Perkerasan Kaku Permeabel dengan Penambahan Serat Sabut Kelapa (Coco Fiber). Universitas Mercubuana: Jakarta

Mariyono, Henry. 2011. Pabrik Calcium Hidroksida dari Calcium Carbonat dengan Proses Dorrco Fluosolids Calciner. Fakultas Teknologi Industri IPN Veteran: Surabaya

Mu'jizah, S. 2010. Pembuatan dan Karakterisasi Karbon Aktif dari Biji Kelor (Moringa Oleifera Lamk) dan $\mathrm{NaCl}$ sebagai Bahan Pengaktif (Skripsi). Universitas Islam Indonesia (UIN) Maulana Malik Ibrahim : Malang.

Novita, E. 2008. Penurunan Intensitas Warna Air Gambut Menggunakan Cangkang Telur sebagai Problem Based Learning Pembelajaran Kimia (Studi Kasus Riau) (Tesis). MIPA ITB : Bandung.

Prodjosantoso, A.k.dan Tutik, Regina, P. 2011. Kimia Lingkungan (Teori, Eksperimen dan Aplikasi). Universitas Negeri Yogyakarta : Yogyakarta

Sebayang, dkk. 2009. Pembuatan Bahan Filter Keramik Berpori Berbasis Zeolit Alam dan Arang Sekam Padi. Pusat Penelitian Fisika LIPI: Tangerang 